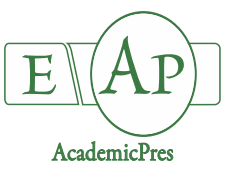

Lin K-H et al. (2021)

Notulae Botanicae Horti Agrobotanici Cluj-Napoca

Volume 49, Issue 1, Article number 12205

DOI: $10.15835 /$ nbha49112205

Research Article

\title{
Influences of sea water on the ethylene-biosynthesis, senescence- associated gene expressions, and antioxidant characteristics of Arabidopsis plants
}

\author{
Kuan-Hung LIN $^{1}$, Meng-Yuan HUANG ${ }^{2}$, Wei-Jun XIE ${ }^{3}$, \\ Shwu-Fen PAN ${ }^{3}$, Yi-Sheng CHEN ${ }^{3}$, Hui-Chung WU ${ }^{3}$, Hsin-Hung LIN ${ }^{1}$, \\ Chih-Ming CHIANG ${ }^{3 *}$
}

\author{
${ }^{I}$ Chinese Culture University, Department of Horticulture and Biotechnology, Taipei 11114, \\ Taiwan; rlin@ulive.pccu.edu.tw; lxh7@ulive.pccu.edu.tw \\ ${ }^{2}$ National Chung Hsing University, Department of Life Sciences, Taichung 40227, Taiwan; hmy6@nchu.edu.tw \\ ${ }^{3}$ Ming Chuan University, Department of Biotechnology, Taoyuan 333, Taiwan; f29017445@gmail.com; sfpan@mail.mcu.edu.tw; \\ yisheng@mail.mcu.edu.tw; joannawu@mail.mcu.edu.tw; cmchiang@mail.mcu.edu.tw ("corresponding author)
}

\begin{abstract}
We evaluated the physiological and antioxidant characteristics of Arabidopsis thaliana (At) plants grown in different sea water (SW) products containing trace elements, namely RO3, 300K, and 340K, at various dilutions. The synthetic water (namely $300 \mathrm{~K}$-Test), a mixture of the main ions of SW including 143.08 $\mathrm{mg} \mathrm{L}{ }^{-1} \mathrm{Mg}^{2+}, 5.74 \mathrm{mg} \mathrm{L}^{-1} \mathrm{Na}^{+}, 170 \mathrm{mg} \mathrm{L}^{-1} \mathrm{~K}^{+}$, and $33.5 \mathrm{mg} \mathrm{L}^{-1} \mathrm{Ca}^{2+}$ with equal concentrations to those in $300 \mathrm{~K}$ SW without trace elements, was also used to culture At plants and study the influences that the major ions had on regulating ethylene production. The ethylene-biosynthesis (ACS7 and ACO2) and senescence-associated (NAP, SAG113, and WRKY6) gene expressions in SW- and ionic-treated At plants in response to transcriptional signaling pathways of ethylene response mechanisms were also investigated. Our results show that down-regulation of the ACS7 gene in 300K-treated plants significantly reduced the ethylene content but remarkably increased chlorophyll, total phenol, and DPPH radical scavenging accumulations and strengthened the salt tolerance of $300 \mathrm{~K}$-treated plants. The expression of the ACS7 gene of At plants under 300K, $\mathrm{Ca}^{2+}$, $\mathrm{Mg}^{2+}$, and $\mathrm{Na}^{+}$treatments was correlated with decreases in NAP, SAG113, and WRKY6 gene expressions. The application of $\mathrm{Ca}^{2+}$ increased total phenol content and reduced the accumulation of superoxide, which in combination decreases plant aging brought on by ethylene. However, $\mathrm{K}^{+}$treatment inhibited SGA113 gene expression, resulting in reducing ACS7 gene expression and ethylene content. The characterization and functional analysis of these genes should facilitate our understanding of ethylene response mechanisms in plants.
\end{abstract}

Keywords: calcium; ethylene; leaf senescence; salinity; sea water; signal transduction

Received: 01 Jan 2021. Received in revised form: 02 Feb 2021. Accepted: 08 Feb 2021. Published online: 10 Feb 2021.

From Volume 49, Issue 1, 2021, Notulae Botanicae Horti Agrobotanici Cluj-Napoca journal will use article numbers in place of the traditional method of continuous pagination through the volume. The journal will continue to appear quarterly, as before, with four annual numbers. 


\section{Introduction}

Sea water (SW) contains abundant essential minerals (i.e. $\mathrm{Mg}^{2+}, \mathrm{Na}^{+}, \mathrm{K}^{+}$, and $\mathrm{Ca}^{2+}$ ), along with minute amounts of many trace elements, and has attracted attention in accordance with a rise of the consciousness of health from the standpoint of preventive medicine (Nakagawa et al., 2000).Studies have shown that SW exerts diverse biological activity, such as regulating the immune system and antioxidant activity in rats (Jung and Joo, 2006). Thus, it has therapeutic effects on lipid metabolism and IgA production (Kang et al., 2015; Shiraishi et al., 2017) and also has been applied in the food, cosmetic, health, and medical fields (Nani et al., 2016; Higgins et al., 2019). Moreover, SW can be favorable for agriculture under certain circumstances, being used as an additional nutrient supplement at different concentrations to improve the nutritional quality of fruits and vegetables (Yudi et al., 2007; Saito et al., 2009; Yamada et al., 2015). Turhan et al. (2014) reported that low concentrations of $S W$ are suitable for lettuce production, which can be successfully grown using $S W$ diluted to concentrations of $2.5 \%$ and $5 \%$. The effects of salt stress induced by SW treatments evaluated in red lettuce showed that tested plants grown with dilute SW accumulated more chlorophyll compared to those grown in $\mathrm{NaCl}$ solutions, thus increasing their quality and nutritional value (Sakamoto et al., 2014). The use of $S W$ has the potential to achieve horticultural crop biofortification, meaning the endogenous nutrient fortification of food (Ding et al., 2016). Atzori et al. (2016) concluded that SW can be used in hydroponics, allowing freshwater savings and increasing certain mineral nutrient concentrations. Furthermore, Caparrotta et al. (2019) also showed that the use of SW treatments in hydroponic spinach cultivation has positive effects on growth parameters.

Senescence is the final phase of leaf development, characterized by key processes in which resources trapped in deteriorating leaves are degraded and recycled to sustain the growth of newly formed organs. As the gaseous hormone ethylene exerts a profound effect on the progression of leaf senescence, both the optimal timing and amount of its biosynthesis are essential for controlled leaf development (Sun et al., 2017). The ethylene biosynthetic pathway in higher plants has been well documented (Yang and Hoffman, 1984). The rate-limiting step is the conversion of S-adenosylmethionine (SAM) to 1-aminocyclopropane-1-carboxylic acid (ACC) catalyzed by ACC synthase (ACS), and finally ethylene is produced through the oxidation of ACC by ACC oxidase (ACO). The regulation of these enzymes is therefore essential for controlling the rate and level of ethylene production. The application of ethylene improves plant tolerance to high salinity, largely by enhancing the expression of reactive oxygen species (ROS) scavengers (Peng et al., 2014). Several key enzymes in ethylene biosynthesis have been addressed as affected by salinity stresses, in which ACS7 is one of the major contributors to the synthesis of ethylene (Dong et al., 2011; Lyzenga et al., 2012). Moreover, ethylene production by ACO2 appears to be a key regulatory step in Arabidopsis plants (Linkies et al., 2009; Sekeli et al., 2014). NAP and WRKY proteins are leaf senescence-associated transcription factor (TF) gene families based on their DNA-binding conserved domains of 60 amino acids with an $\mathrm{N}$ terminus and a $\mathrm{C}_{2} \mathrm{H}_{2}$ zinc-finger motif at the C terminus (Zhang and Gan, 2012; Kou et al., 2012; Guet al., 2019). Senescence-associated gene113 (SAG113), a gene encoding a Golgi-localized protein phosphatase 2C family protein phosphatase, mediates abscisic acid (ABA)-regulated stomatal movement and water loss specifically during leaf senescence. Previous studies showed that high accumulations of the ACS7 protein lead to precocious leaf senescence as well as greatly up-regulating the expressions of NAP, WRKY6, and SAG113 genes (Robatzek and Somssich, 2002; Sun et al., 2017).The study presents the expressions of these ethylene-biosynthesis and senescence-associated genes involving the signaling transduction pathways for delaying senescence in Arabidopsis plants treated with $\mathrm{SW}$ and its major ionic solutions.

Previously, we reported that various dilution rates of commercial SW applied to pakchoi (Brassica rapa subsp. Chinensis) and tomato (Solanum lycopersicum var. cerasiforme) in hydroponic cultivation conditions enhanced cell viability by increasing 1,1-diphenyl- 2-picrylhydrazyl (DPPH) scavenging ability and 2.3.5triphenyl tetrazolium chloride (TTC) activity and decreasing malondialdehyde (MDA) content in tested plant leaves compared with plant leaves without SW treatment (Xie et al., 2020). TTC activity was used as a 
quantitative method in the evaluation of cell viability, while the higher TTC activity the higher cell viability. MDA is a final decomposition product of lipid peroxidation and has been used as an index for the status of lipid peroxidation, the lower the MDA content the higher cell viability. In the present study, Arabidopsisplants grown in different concentrations of $S W$ were evaluated for their physiological and antioxidant characteristics. The influences that the major ions $\left(\mathrm{Mg}^{2+}, \mathrm{Na}^{+}, \mathrm{K}^{+}\right.$, and $\left.\mathrm{Ca}^{2+}\right)$ contained in $\mathrm{SW}$ have on regulating ethylene production were determined. Salt ion analysis revealed significantly different accumulations of $\mathrm{Mg}^{2+}, \mathrm{Na}^{+}, \mathrm{K}^{+}$, and $\mathrm{Ca}^{2+}$ between bent grass cultivars in response to salt stress (Krishnan and Merewitz, 2015). Understanding how ethylene profiles change will help elucidate the mechanisms governing salt-stress tolerance in plants, in which ethylene inhibits receptors, suppresses salt sensitivity conferred by ethylene receptors, and promotes ethylene-responsive salt tolerance (Cao et al., 2007).In addition, in order to test whether ethylene is involved in transcriptional regulation signaling pathways during SW and ionic treatments, expression patterns among the ethylene-biosynthesis and senescence-associated genes in SW-and ionic-treated At plants in response to ethylene production are also discussed to facilitate our understanding of ethylene response mechanisms, the physiological and molecular aspects of salt stress sensing functions, and improve plant stress tolerance, all of which are critical for plant growth and productivity.

\section{Materials and Methods}

\section{Germination test and growth conditions}

One hundred seeds of Arabidopsis thaliana (At) L. ecotype Columbia were sterilized with 1.5\% sodium hypochlorite and rinsed with distilled deionized $(\mathrm{dd}) \mathrm{H}_{2} \mathrm{O}$. Seeds were then germinated and grown in half strength Murashige-Skoog (MS, from Sigma-Aldrich Co., San Jose, CA, USA) in Petri dishes for two weeks after sowing in a growth chamber under $200 \mu \mathrm{mol} \mathrm{m}^{-2} \mathrm{~s}^{-1}$ light with a $16 \mathrm{~h}$ photoperiod at a temperature of 23 ${ }^{\circ} \mathrm{C}$, and a relative humidity of $80 \%$ for a week. The germination rate (\%) was then calculated (Chiang et al., 2014). Three commercial SW products (namely RO3,300K, and $340 \mathrm{~K}$ ), each in three different dilution ratios, were applied to determine the optimal dilution rate $(\mathrm{X})$ without influencing seed germination and seedlings by comparing with those plants without SW treatment (control). Uniformly sized three-week old seedlings were individually transferred to 3 -inch $(7.6 \mathrm{~cm})$ plastic pots, and treated with $100 \mathrm{~mL}$ of each SW and complete nutrient solution (Millero et al., 2008; Caparrotta et al., 2019) once per week. Pots were randomly placed in the above-mentioned growth chamber under the same growing conditions for one week.

Table 1 lists the characteristics of the three commercial SW products at various dilutions and 300KTest synthetic water suitable for plant growth: $\mathrm{RO} 3$ (2,000 X, high $\mathrm{Na}^{+}$-containing SW with trace elements), $300 \mathrm{~K}\left(540 \mathrm{X}\right.$, high $\mathrm{Mg}^{2+}, \mathrm{K}^{+}$, and $\mathrm{Ca}^{2+}$-containing ocean water with trace elements), $340 \mathrm{~K}\left(6,180 \mathrm{X}\right.$, high $\mathrm{Mg}^{2+}$, $\mathrm{K}^{+}$, and $\mathrm{Na}^{+}$-containing $\mathrm{SW}$ with trace elements), and $300 \mathrm{~K}$-Test (major ions with equal concentrations to that in $300 \mathrm{~K} \mathrm{SW}$ without trace elements) compared to those non-SW treated plants. Electrical conductivity (EC) and $\mathrm{pH}$ values of three SWs and 300K-Test solution were measured by an EC meter (DEC-2, Atago Co., Tokyo, Japan) and $\mathrm{pH}$ meter (DPH-2, Atago Co.), respectively. Their values were calculated by using the concentrations of the major constituents $\left(\mathrm{Mg}^{2+}, \mathrm{Na}^{+}, \mathrm{K}^{+}\right.$, and $\mathrm{Ca}^{2+}$ ) in the commercial SW (Sakamoto et al., 2014). In addition, the mixture of $\mathrm{Mg}^{2+}, \mathrm{Na}^{+}, \mathrm{K}^{+}$, and $\mathrm{Ca}^{2+}$ synthetic water (same as $300 \mathrm{~K}$ but free of trace elements, namely $300 \mathrm{~K}-\mathrm{Test}$ ) was also used to culture At plants in order to assess the effects of these major ions on the physiological and antioxidant characteristics on the plants compared to $300 \mathrm{~K}(540 \mathrm{X}) \mathrm{SW}$. The " $300 \mathrm{~K}$ Test" ion synthetic water contained equal amounts and concentrations of the major ions $\mathrm{Mg}^{2+}(143.08 \mathrm{mg} \mathrm{L}$ $\left.{ }^{1}\right), \mathrm{Na}^{+}\left(5.74 \mathrm{mg} \mathrm{L}^{-1}\right), \mathrm{K}^{+}\left(170 \mathrm{mg} \mathrm{L}^{-1}\right)$, and $\mathrm{Ca}^{2+}\left(33.5 \mathrm{mg} \mathrm{L}^{-1}\right)$ as in the commercial $300 \mathrm{~K}$ (540X) SW but free of trace elements (Sohrin et al., 1998). The $\mathrm{pH}$ of the 300K-Test was adjusted to 5.7, identical to the three commercial SW products. The EC value of $300 \mathrm{~K}$-Test was $1.082(\mathrm{~ms} / \mathrm{cm})$, with obtained values being reported in Table 1. 
Table 1. Constituent, $\mathrm{pH}$ value, and electrical conductivity (EC) value of three commercial sea water products [SW - RO3 (2,000X), 300K (540X), and 340K (6,180X)] and a mixture of $\mathrm{Mg}^{2+}, \mathrm{Na}^{+}, \mathrm{K}^{+}$, and $\mathrm{Ca}^{2+}$ ions only (namely $300 \mathrm{~K}-\mathrm{Test}$, free of trace elements)

\begin{tabular}{|c|c|c|c|c|}
\hline $\begin{array}{c}\text { Solution } \\
\text { (concentration) }\end{array}$ & $\begin{array}{c}\mathrm{RO} 3 \\
(2,000 \mathrm{X})^{*}\end{array}$ & $\begin{array}{c}300 \mathrm{~K} \\
(540 \mathrm{X})^{*}\end{array}$ & $\begin{array}{c}340 \mathrm{~K} \\
(6,180 \mathrm{X})^{*}\end{array}$ & $300 \mathrm{~K}-\mathrm{Test}$ \\
\hline $\mathrm{Mg}^{2+}\left(\mathrm{mg} \mathrm{L}^{-1}\right)$ & 1.125 & 143.08 & 3.8 & 143.08 \\
\hline $\mathrm{Na}^{+}\left(m g L^{-1}\right)$ & 8.65 & 5.74 & 4.7 & 5.74 \\
\hline $\mathrm{K}^{+}\left(\mathrm{mg} \mathrm{L}^{-1}\right)$ & 3.3 & 170 & 41.2 & 170 \\
\hline $\mathrm{Ca}^{2+}\left(\mathrm{mg} \mathrm{L}^{-1}\right)$ & 0.38 & 33.5 & 0.0017 & 33.5 \\
\hline Trace elements & + & + & + & - \\
\hline Salinity ratio & 1 & 0.27 & 3.09 & - \\
\hline $\mathrm{pH}$ value & 5.7 & 5.7 & 5.7 & 5.7 \\
\hline $\mathrm{EC}$ value $(\mathrm{ms} / \mathrm{cm})$ & 0.1184 & 1.458 & 0.01746 & 1.082 \\
\hline
\end{tabular}

${ }^{*}$ The three commercial SW was obtained from LOHA Water Tech Co., Taipei, Taiwan, and processed though electrodeionization and vacuum concentration. RO3 was used as the basic level, set as 1 to calibrate the salinity ratios of $300 \mathrm{~K}$ (0.27) and $340 \mathrm{~K}$ (3.09). Trace elements such as zinc, manganese, vanadium, chromium, and selenium are negligible in these three commercial SW solutions.

+: with trace elements; -: without trace elements.

The SW was obtained from LOHA Water Tech Co., Taipei, Taiwan, and processed though electrodeionization and vacuum concentration. However, high salinity from the non-diluted SW had a harmful effect on seed germination. RO3 was then used as the basic level, set as 1 to calibrate the salinity ratios of $300 \mathrm{~K}(0.27)$ and $340 \mathrm{~K}$ (3.09). Afterward, three various diluted rates $(\mathrm{X})$ of each SW were established according to the salinity ratio and diluted with dd water to the same salinity. For example, the three dilution rates (500X, $1,000 \mathrm{X}$, and 2,000X) of RO3 were multiplied by 0.27 and 3.09 to obtain the three dilution rates (135X, 270X, and $540 \mathrm{X}$ ) of $300 \mathrm{~K}$ and $(1,545 \mathrm{X}, 3,090 \mathrm{X}$, and 6,180X) 340K, respectively (Table 1). RO3 (500X) was used in equal concentration to that of $300 \mathrm{~K}(135 \mathrm{X})$ and $340 \mathrm{~K}(1,454 \mathrm{X}) \mathrm{SW}$ for studying the influences of the main elements and trace elements in SW on Arabidopsis plants.

Each different dilution rate of each SW treatment was applied to 100 seedlings or plants in the experiment in a completely randomized design. The At plants grown under 1/2 MS medium without SW and $300 \mathrm{~K}-$ Test treatments served as controls. Following each treatment, young, fully expanded leaves from each plant were clipped, frozen in liquid nitrogen, and stored at $-80^{\circ} \mathrm{C}$ in an ultra-freezer until used for the analyses.

Determination of total chlorophyll, phenolic, and MDA contents, DPPH scavenging capacity, enzyme activity, and in situ ROS staining

The total Chl content of leaves from three-week-old potted At plants from each treatment were determined using methods described by Arnon (1949). The analysis of DPPH radical scavenging activity in At leaf extracts was determined according to Shimada et al. (1992). The DPPH scavenging capacity was calculated as the percentage of free radical-scavenging activity. The measurement of MDA content using the thiobarbituric acid (TBA)-trichloroacetic acid (TCA) method was described by Kosugi and Kikugawa (1985). Ten plants per treatment were used for all analyses.

Cut leaves from each treatment were prepared for superoxide dismutase (SOD, EC 1.15.1.1), catalase (CAT, EC 1.11.1.6), glutathione reductase (GR, EC 1.6.4.2), and ascorbate peroxidase (APX, EC 1.11.1.11) activity analyses. SOD activity was analyzed using a SOD assay kit (Dojindo Molecular Technology, Gaithersburg, MD, USA). CAT activity was determined as described by Hwang and VanToai (1991). APX 
activity was determined according to Nakano and Asada (1981). GR activity was measured by the GSHdependent oxidation of NADPH according to Foyer et al. (1997).

The total phenolic content of leaves in each treatment was described in Dewanto et al. (2002). The total phenolic concentration is expressed as gallic acid equivalents per gram of dry weight (GAE, mg gallic acid/g sample) using a calibration curve with gallic acid. The calibration curve ranged from 20 to $500 \mathrm{mg} / \mathrm{ml}\left(\mathrm{R}^{2}=\right.$ 0.996).

ROS were stained in situ utilizing the principle of nitroblue-tetrazolium (NBT) reduction to blue formazan by superoxide radicals. The intracellular concentration of superoxide radicals was directly proportional to the development of the intensity of blue color in the leaves and previously described in Shafi et al. (2014).

Expression analysis of ethylene-synthesis and senescence-associated genes, amplification of cDNA, and quantification of $R N A$ levels

Three-week-old plant leaves $(0.1 \mathrm{~g})$ with $S W$ and ionic one-week treatments were used for total RNA isolation using an Ambion Kit (San Francisco, CA, USA). Paired specific primers for AtActin8, ACS7, ACO2, NAP, SAG113, and WRKY6 were used for amplification (Table 2). Gene amplification was described in our previous study (Lin et al., 2019). The products were electrophoretically separated on 1.5\% agarose gels, and predicted sizes of 140, 88, 166, 84, 130, and 84bp of AtActin8 (accession no. At1g49240), ACS7 (accession no. AT4G26200), ACO2 (accession no. AT1G62380), NAP (accession no. AT1G69490), SAG113 (accession no. AT5G59220), and WRKY6 (accession no. AT1G62300) genes, respectively, were verified with a 100bp DNA ladder marker.

The relative changes in ethylene-synthesis (ACS7 and ACO2) and senescence-associated (NAP, SAG113, and WRKY6) gene expressions in response to various diluted SW and their four major ionic $\left(\mathrm{Mg}^{2+}\right.$, $\mathrm{Na}^{+}, \mathrm{K}^{+}$, and $\mathrm{Ca}^{2+}$ ) treatments were monitored by real-time quantitative (q)PCR and quantification of RNA levels. To test whether NAP, SAG113, and WRKY6gene expressions were induced by ethylene, two-week-old At plants were foliar sprayed by $1 \mathrm{mM}$ ethephon aqueous solution (Sigma-Aldrich Cat.\# C0143) for one week as previously described (Wen et al., 2015). A real-time qPCR was performed based on our previous study (Lin et al., 2019). To normalize the total amount of cDNA in each reaction, AtActin- 8 from Arabidopsis was coamplified asan internal control. The relative amounts of RNA were calculated by the ratio of the abundance of $300 \mathrm{~K}$ - and major ionic-treated plants to AtActin- 8 (Livak and Schmittgen,2001).

Table 2. Pairedprimers for AtActin 8 (internal control), ACS7 and $A C O 2$ (ethylene-biosynthesis genes), NAP, SAG113, and WRKY6 (senescence-associated genes) used in the study

\begin{tabular}{|c|c|c|}
\hline Primers & Sequence (5' to 3') & Size $(\mathrm{pb})$ \\
\hline AtActin8 & F: 5'CCCAA AAGCC AACAG AGAGA3' & 140 \\
& R: 5'CATCACCAGAGTCCAACACAAT3' & 88 \\
\hline ACS7 & F: 5'TCGTGACGCGAACATTAGAG3' & \\
\hline RCO2 & R'TCTAGAACCTTCTTTTGGACC3' & 166 \\
\hline NAP & F: 5'CCAGCTACTTCGCTTGTCGAC3' & 84 \\
\hline RAG113 & F: 5'GTCTCTACGGCTGCTGTAGGA3' & 130 \\
\hline WRKY6 & R: 5'CCGAACCAACTAGACTCCGA3' & 84 \\
\hline
\end{tabular}




\section{Ethylene emission measurements}

The rate of evolution of ethylene was determined on four-week-old At plants (10 different leaves of one rosette and ten plants per treatment) with a portable ethylene gas analyzer (CI-900; CID Bio-Science, Camas, WA, USA). Pots were kept inside the airtight chamber of the instrument for $2 \mathrm{~min}$ and their rates of ethylene evolution (ppm) (Krishnanand Merewitz, 2015) were read.

\section{TTC activity determination of At seeds}

The data on seed viability by TTC activity test were also recorded up to seven days after sowing and ten plants were used for each treatment. TTC analysis was performed based on Hussain and Reigosa (2014) using ELISA Reader (Spectrophotometer U-2900, Hitachi Tokyo, Japan) and expressed as $\mathrm{A}_{485} \mu \mathrm{g}$ per plant weight (g) per hour (h).

\section{Statistical analysis}

The measurements of physiological and antioxidant parameters were performed using a paired $t$-test and one-way analysis of variance (ANOVA), with the least significant difference (LSD) test at $p<0.05$ using the SAS program ver. 9 (SAS Institute, Cary, NC, USA).

\section{Results and Discussion}

\section{Morphology of At seedlings}

The At seedlings grown in 1/2 MS medium with RO3 (500X, 1,000X, and 2,000X), 300K (135X, 270X, and 540X), and 340K (1,545X, 3,090X, and 6,180X) treatments were impaired, epinastic, senescent, yellowish, and smaller in size relative to all of the control plants (photos not shown). On the other hand, no obvious differences were observed in the colors and sizes of seedlings cultivated in the highest dilution ratios (lowest concentrations) of SW treatments and controls. However, higher concentrations of SW displayed inhibitory effects on growth from salinity, and salt stressed seedlings suffered a changed cell water relation that displayed a cost for osmotic adjustment, which generally reduced the absorption and translocation of water (Munns, 2002). In fact, salinity negatively affects plant growth and physiology through different mechanisms, such as water and osmotic stress (Garcia-Sanchez and Syvertsen, 2009; Balal et al., 2012; Gonzalez et al., 2012). It is generally known that when $S W$ is provided to plants during cultivation, minerals contained in the seawater may stimulate growth. Islam et al. (2010) reported that eggplant variety 'Ryoma' plants grown with the applications of $2 \%$ mineral controlled sea water to the standard nutrient solution under greenhouse condition had larger vegetative growth rate than with the control. Furthermore, with the $2 \%$ mineral controlled sea water treatment the plants increased $14 \%$ of fruit yield compared to the control. For Arabidopsis tolerance to salinity stress, Alet et al. (2012) reported that the inhibitory effects were observed when plants were grown under $>50$ $\mathrm{mM} \mathrm{NaCl}$ conditions. Throughout the duration of the experiment, seedlings appeared healthy and sported green and larger leaves when cultivated in the higher dilution ratios of $\mathrm{RO} 3,300 \mathrm{~K}$, and $340 \mathrm{~K}$ treatments, withstanding the low osmotic pressure of the growing medium, in comparison to the above-mentioned lower dilution ratios. Therefore, RO3, 300K, 340K, and 300K-Test treatments were used for the following experiments. Moreover, these identified dilution systems could be used for the rapid monitoring and early detection of salt injury in the seedling stage. This means that hundreds of individual plants might be screened per day, providing for the large-scale discovery of individuals that exhibit tolerance to salt stress.

\section{Physiological and antioxidant characteristics of At seeds and plants}

No significant differences in the germination rates of At seeds were observed among all treatments and controls, with an average of $95.5 \%$ germination (Figure 1A), suggesting that diluted SW does not affect At seed germination due to its tolerance to low salinity stresses. TTC activity responded differently to diluted SW 
treatments (Figure 1B), and TTC activity of Arabidopsis seeds cultivated in $300 \mathrm{~K}$ and $340 \mathrm{~K}$ at an average of $7.3 \mu \mathrm{g} / \mathrm{g} \cdot \mathrm{h}$ was significantly higher than in controls, which averaged $6 \mu \mathrm{g} / \mathrm{g} \cdot \mathrm{h}$, whereas seeds under RO3 treatment displayed similar TTC activity to controls. Thus, $300 \mathrm{~K}$ and $340 \mathrm{~K} \mathrm{SW}$ improved cell activity in seeds compared to RO3 and controls, suggesting that SWs with different concentrations of $\mathrm{Mg}^{2+}, \mathrm{K}^{+}$, and $\mathrm{Ca}^{2+}$ (Table 1) may influence the tissue cell viability of At plants. The MDA content of all leaves grown in all SW treatments and controls did not show any significant differences (Figure 2A). Therefore, the SW concentrations used in the present experiment were unable to induce any change in MDA content - in other words, decreased lipid peroxidation- in the leaves of At plants, suggesting the possibility of cultivation at the tested SW concentrations. Thus, SWs with different $\mathrm{Mg}^{2+}, \mathrm{K}^{+}$, and $\mathrm{Ca}^{2+}$ concentrations (Table 1) would not cause the tissue cells of At plants to produce lipid peroxidation. Alternatively, SW treatments to Arabidopsis maintained the integrity of the plasma membrane, and the integrity of the cell wall reflected on reduced lipid peroxidation status in the At plants, which might be related to reducing leaf MDA content.

A.

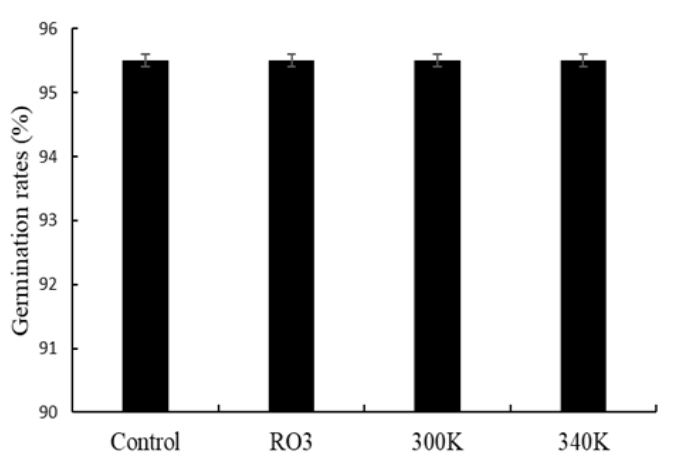

B.

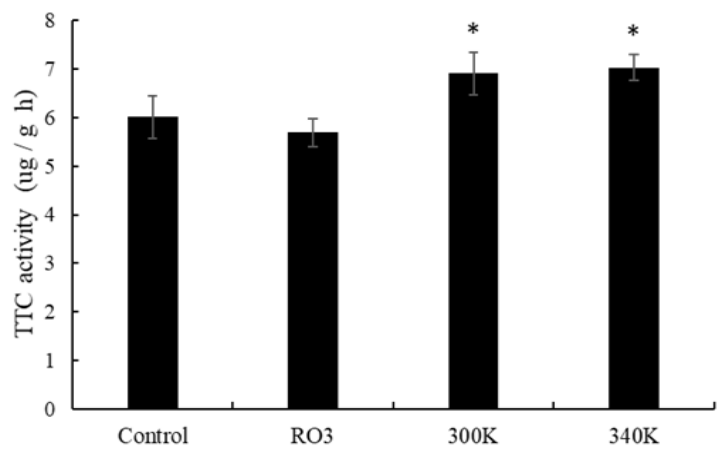

Figure 1. Seeds of Arabidopsis thaliana treated with diluted RO3, 300K, and 340K treatments for a week followed by the germination test (A) and TTC activity determination (B) Arabidopsis thaliana plants grown in 1/2 MS medium without SW treatments were controls. Values are the means of eight replicates with corresponding standard deviations. The germination rate (\%) and TTC activity $(\mu \mathrm{g} / \mathrm{g} \cdot \mathrm{h})$ are compared to control plants and an asterisk indicates a significance level of $p \leq 0.05$.

The significantly higher DPPH radical scavenging effect ( $41.2 \%)$ and total Chl content $(0.58 \mathrm{mg} / \mathrm{g} \mathrm{FW})$ in tested leaves were observed with $300 \mathrm{~K}$ compared to the control ( $40.4 \%$ and $0.48 \mathrm{mg} / \mathrm{g} \mathrm{FW}$, respectively), whereas no remarkable differences in DPPH radical scavenging effects and total Chl content were detected among RO3, 340K, and controls (Figures 2B,C). These results demonstrate that only 300K treatment could increase antioxidant content and scavenge DPPH radicals, and also suggests that the major ions contained in $300 \mathrm{~K} \mathrm{SW}$ may enhance the synthesis and accumulation of Chl. Magnesium is a main constituent of the Chl molecule bound by four pyroll groups. Consequently, using a remarkably high concentration $\left(143.08 \mathrm{mg} \mathrm{L}^{-1}\right)$ of $\mathrm{Mg}^{2+}$ in the $300 \mathrm{~K}$ solution could critically influence the additional synthesis of $\mathrm{Chl}$ in the leaves. Furthermore, $300 \mathrm{~K}$-treated At plants exhibited lower accumulations of superoxide $\left(\bullet \mathrm{O}^{2-}\right)$ in leaves compared to other SW treatments and controls in in situ ROS staining (Figure 2D), speculating that plants treated with diluted $300 \mathrm{~K}$ had slightly lower ROS accumulations compared to the control. In addition, $\mathrm{Mg}^{2+}, \mathrm{Na}^{+}, \mathrm{K}^{+}, \mathrm{Ca}^{2+}$, and $300 \mathrm{~K}$ also displayed lower levels of $\bullet \mathrm{O}^{2-}$ accumulation in leaves as evidenced by the lower intensity of a fuscous precipitant (blue color) compared to the control (Figure 2E). Therefore, $300 \mathrm{~K}, \mathrm{Mg}^{2+}, \mathrm{Na}^{+}, \mathrm{K}^{+}$, and $\mathrm{Ca}^{2+}$ solutions were applied to tested plants for antioxidant capacity analysis. 
A.

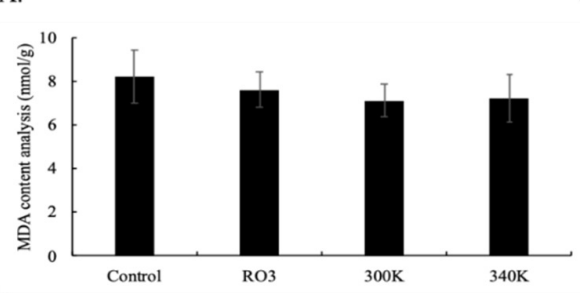

C.

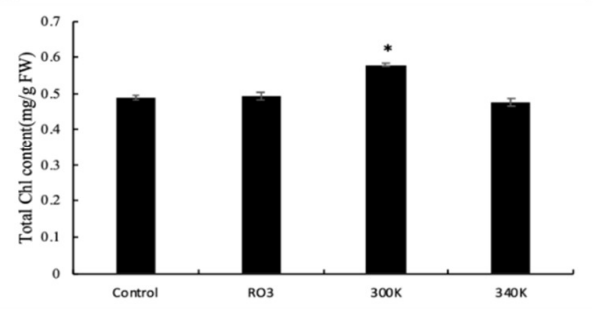

B.

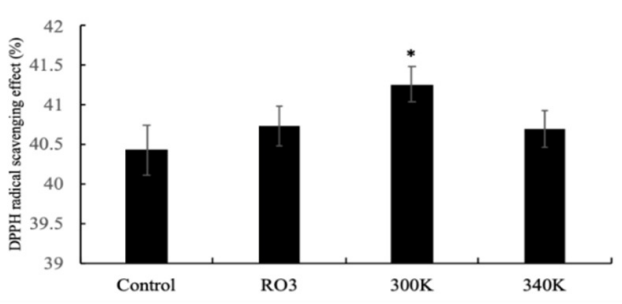

D.

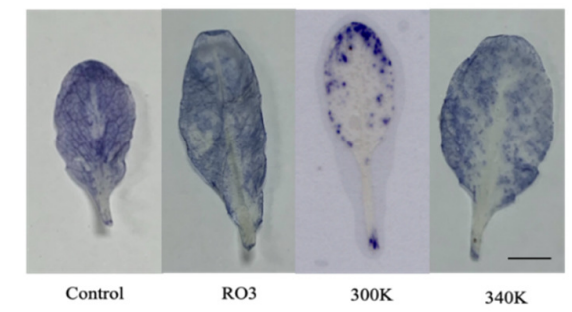

E.

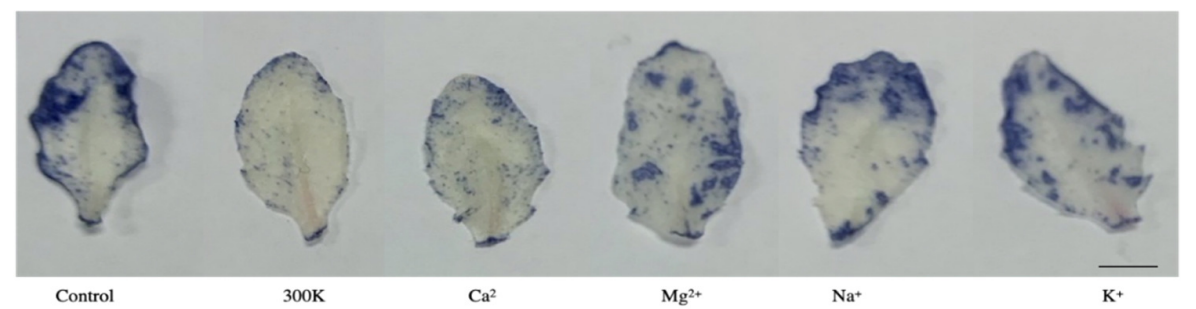

Figure 2. Three-week old potted Arabidopsis thaliana plants treated with diluted RO3, 300K, and 340K SW for one week followed by the measurement of MDA content (A), DPPH scavenging ability (B), total chlorophyll content (C), and NBT staining of leaves (D)

Panel E is NBT staining in leaves of the same plants treated for one week with diluted $300 \mathrm{~K}, \mathrm{Mg}^{2+}, \mathrm{Na}^{+}, \mathrm{K}^{+}$, and $\mathrm{Ca}^{2+}$. Controls were Arabidopsis thaliana plants grown in $1 / 2 \mathrm{MS}$ medium without SW or ionic treatments. Values are the means of eight replicates with corresponding standard deviations. The MDA content (nmol/g), DPPH scavenging ability (\%), and total chlorophyll content $(\mathrm{mg} / \mathrm{g} \mathrm{FW}$ ) are in comparison to control plants and an asterisk indicates a significance level of $p \leq 0.05$. Scale bar size is $0.5 \mathrm{~cm}$.

Plants offset the initial osmotic components of salt stress by adjusting the osmotic gradient, although the accumulation of $\mathrm{Na}^{+}$can lead to toxic effects in the long term (Alvarez-Aragon and Rodriguez-Navarro, 2017). $\mathrm{Na}^{+}$affects the hydration shell of other molecules, causes damage to the cell wall, disturbs the $\mathrm{K}^{+} / \mathrm{Na}^{+}$ ratio of cells by several mechanisms, and impairs plant physiology (Julkowska and Testerink, 2015). Generally, plants that have the ability to excrete, exclude, or tolerate high levels of salt are salt-resistant, the differential expression genes of proton pumps or antioxidant capacity could play a role in causing the differential accumulation of $\mathrm{Na}^{+}$in plant leaves and roots between cultivars (Janicka-Russak et al., 2013; Pérez-López et al., 2013; Krishnan and Merewitz, 2015). In addition, the maintenance of all $\mathrm{K}^{+}$ion transporters and channels across the plasma membrane is essential for proper $\mathrm{K}^{+}$homeostasis in plants (Zhang et al., 2018). Calcium can also improve $\mathrm{K}^{+}$transport under salt stress conditions (Maathuis, 2006). Although plants rely on a sufficient supply of $\mathrm{Mg}^{2+}$ and other elements for normal growth and development, excessive $\mathrm{Mg}^{2+}$ accumulation often causes toxicity to plant cells (Niu et al., 2018). Salt movement and accumulation in roots and leaves of At plants subjected to SW and ionic treatments for their contrasts in salt tolerance are worthy of further investigation.

Arabidopsis plants treated with $300 \mathrm{~K}$ and $\mathrm{Ca}^{2+}$ cultures showed significantly higher total phenolic content $(18 \mathrm{mg}$ of GAE/g and $22 \mathrm{mg}$ of GAE/g, respectively) compared to the control $(13 \mathrm{mg}$ of GAE/g) (Figure 3E). Nevertheless, no significant differences were observed between $\mathrm{Mg}^{2+}, \mathrm{Na}^{+}, \mathrm{K}^{+}$, and $\mathrm{Ca}^{2+}$ alone or combined $(300 \mathrm{~K}$ and $300 \mathrm{~K}-T e s t)$ in cultures and controls. The four antioxidant activities of At leaf extracts from $300 \mathrm{~K}$ and all individual ionic cultures were non-significantly different from controls (Figures 3A-D), suggesting that CAT, SOD, APX, and GR did not participate in active ROS reduction irrespective of the plant 
growth period (three weeks after sowing) when treated with $300 \mathrm{~K}$ and those four major ions.ROS production and scavenging are interactive, maintaining relative stability in plants.

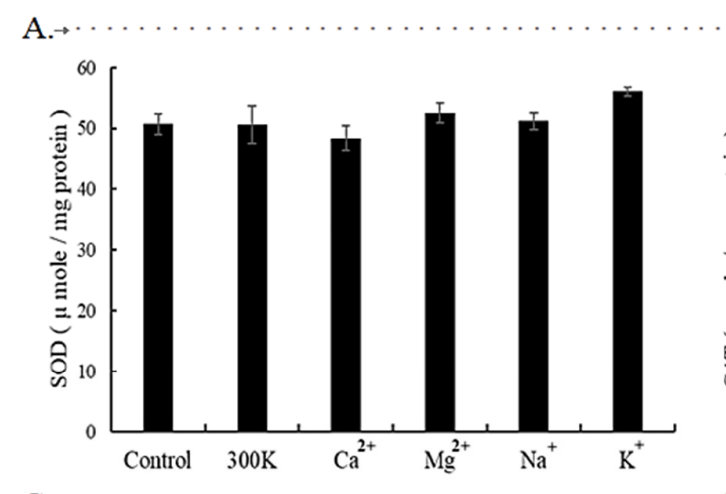

B.
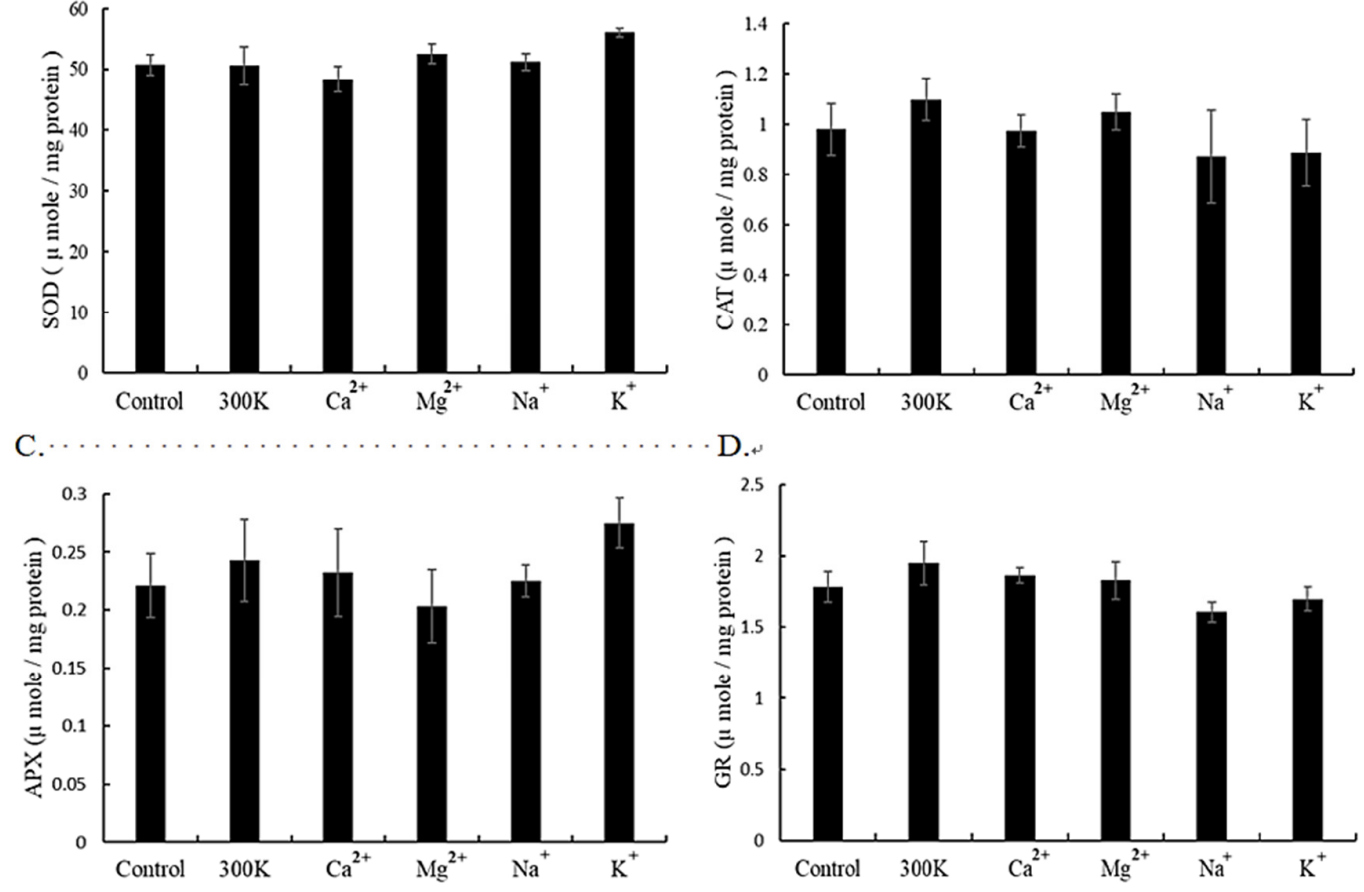

E.

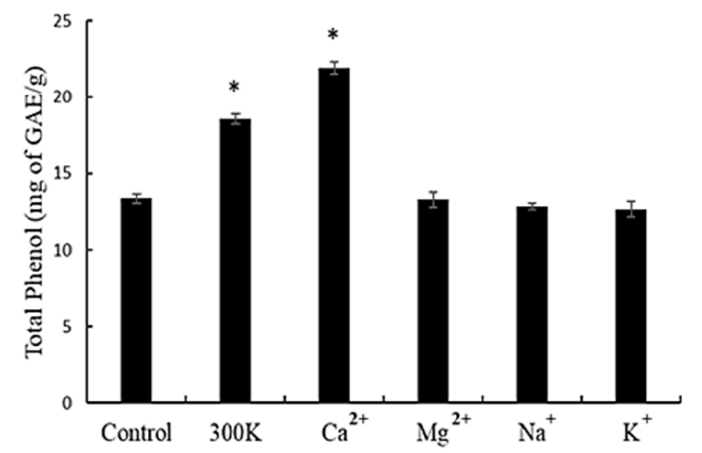

Figure 3. Three-week old potted Arabidopsis thaliana plants treated for one week with diluted 300K, $\mathrm{Mg}^{2+}, \mathrm{Na}^{+}, \mathrm{K}^{+}$, and $\mathrm{Ca}^{2+}$, followed by analysis of SOD activity (A), CAT activity (B), APX activity (C), GR activity (D), and total phenol content (E)

Controls were Arabidopsis thaliana plants grown in 1/2 MS medium without SW or ionic treatments. Values are the means of eight replicates with corresponding standard deviations. The SOD, CAT, APX, and GR activities (U/mg protein) and total phenol contents ( $\mathrm{mg}$ of $\mathrm{GAE} / \mathrm{g}$ ) are in comparison to control plants, and an asterisk indicates a significance level of $p \leq 0.05$.

Presumably, the accumulation of antioxidant system components and ROS formation are favored in salt tolerance. Increased levels of ROS in salt-stressed plants could lead to an increased capacity of the ROS scavenging system. Salt stress induces the production of ROS such as singlet oxygen $\left(1 \mathrm{O}_{2}\right)$, superoxide radicals $\left(\mathrm{O}_{2}{ }^{-}\right)$, hydrogen peroxide $\left(\mathrm{H}_{2} \mathrm{O}_{2}\right)$, and hydroxyl radicals $\left(\mathrm{OH}^{*}\right)$. These ROS are necessary for inter- and intracellular signaling, but at high concentrations they seriously disrupt normal metabolism in plants through the oxidation of membrane lipids, proteins, and nucleic acids (Hoque et al., 2007). Numerous studies have 
indicated that antioxidant systems are correlated with plant tolerance to salt stress, these enzymes and/or nonenzymes are required to maintain redox homeostasis, and the induction of antioxidants and osmolytes is part of an integrated strategy for salt stress defense (Lin and $\mathrm{Pu}, 2010$ ). Pre-treating with SW and ionic solutions may influence the ability to maintain a balance between the formations and de-oxidation of ROS, leading to leaf vulnerability against oxidative stress. Salt stresses induce the production of ROS, which are necessary for inter-and intracellular signaling, but under stress conditions they seriously disrupt normal metabolism in plants through the oxidation of membrane lipids, proteins, and nucleic acids in the absence of protective mechanisms (Nguyen et al., 2018). In our study, total phenolic content is markedly accumulated in At leaves exposed to salinity stress, suggesting that total phenol content may be useful in screening salt-tolerant plants.

Increased DPPH radical scavenging activity was observed in the extracts of At grown in cultures with $300 \mathrm{~K} \mathrm{SW}$, which may be due to the contribution of phenolics accumulated in the leaves. Supplementation of $300 \mathrm{~K} \mathrm{SW}$ increased the salinity of the nutrient solution and subsequently might increase the $\mathrm{Ca}^{2+}$ uptake; thus, leaves contained more total phenolic content. The phenolic compound alteration due to salinity stress is critically dependent on the salt sensitivity of the plant. In fact, salt stress creating both ionic as well as osmotic stress in plants resulting in increased polyphenol concentration indifferent tissues have been reported in a number of plants (Parida and Das, 2005). We assume that At plants were subjected to osmotic stress by the addition of $\mathrm{Ca}^{+2}$ to the cultures, and as a result, phenolics are produced and accumulate in leaf cells and function as osmolytes, and are believed to facilitate osmotic adjustments by acting as osmoprotectants. Errabii et al. (2006) reported that growth, proline and ion accumulation in sugarcane callus cultures under drought-induced osmotic stress and its subsequent relief, and a sudden osmotic up shift in the medium causes a water efflux from the cells, loss of turgor pressure, and concomitant reduced growth. It is known that hyperosmolality and various other stimuli trigger increases in cytosolic free calcium concentration. Environmental water deficiency triggers an osmotic stress signaling cascade, which induces short-term cellular responses to reduce water loss and longterm responses to remodel the transcriptional network and physiological and developmental processes (Yuan et al., 2014). The cell wall also contains phenolics, enzymes, proteins, and $\mathrm{Ca}^{2+}$, and osmotic stress can lead to the accumulation of ROS in the cell wall (Tenhaken, 2014). The calcium ion acts at a convergence point for integrating different signals, and may have a role in providing salt tolerance to plant cells. Some oxidant systems use $\mathrm{Ca}^{2+}$ to stimulate oxidative bursts in leaf cells, but some do not. Manipulating $\mathrm{Ca}^{2+}$ homeostasis by altering the concentration of $\mathrm{Ca}^{2+}$ could be an important strategy to alter the behavior and survival of plants under salt stress (Lin et al., 2008). As a consequence, $\mathrm{Ca}^{2+}$ may play an important role in the antioxidant system under salt stress. It is possible that both calcium and ROS could be important modulators of the cellular signaling of transduction events following salt-stress injury. Perhaps a higher level of $\mathrm{Ca}^{2+}$ under non-stressed conditions allows for enhanced stress perception, signaling, or $\mathrm{Ca}^{2+}$-induced stabilization of cell structure at the onset of salt stress. The development of salt stress in leaves was more gradual or perhaps delayed by $\mathrm{Ca}^{+2}$ with $33.5 \mathrm{mg}$ $\mathrm{L}^{-1}$ treatment.

\section{Determination of ACS7 and ACO2 genes expression and ethylene emission in At plants with ethephon treatment}

Ethylene biosynthesis may have resulted from gene activation and/or up-regulation of ethylene-induced ACS7 and ACO2 genes. To investigate the regulation and expression of ACS7 and ACO2 genes in At plants, a real-time qPCR analysis was performed with extracted RNA from two-week-old plants subjected to diluted SW and 300K-Test solutions for one week. Data were normalized with respect to the RNA level of AtActin8, a housekeeping gene that is consistently expressed in plants. Figures $4 \mathrm{~A}$ and $\mathrm{B}$ show that RNA abundances of $A C S 7$ and $A C O 2$ were significantly up-regulated in $\mathrm{RO} 3$ and $340 \mathrm{~K}$ treatments in comparison to controls. However, RNA expressions of $A C S 7$ were significantly lower in $300 \mathrm{~K}, 300 \mathrm{~K}-\mathrm{Test}$, and individual $\mathrm{Ca}^{2+}, \mathrm{Mg}^{2+}$, and $\mathrm{Na}^{+}$in $300 \mathrm{~K}$ solutions than in controls (Figures $4 \mathrm{~A}$ and C). Moreover, the ACS7 gene was significantly and highly expressed in $\mathrm{K}^{+}$-treated plants compared to control plants. 

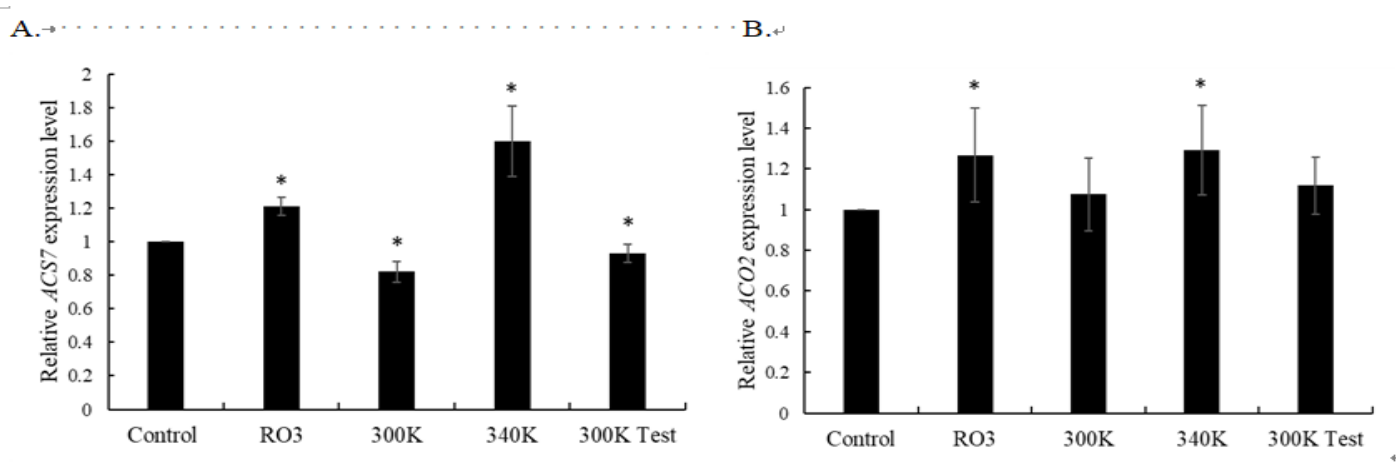

C.

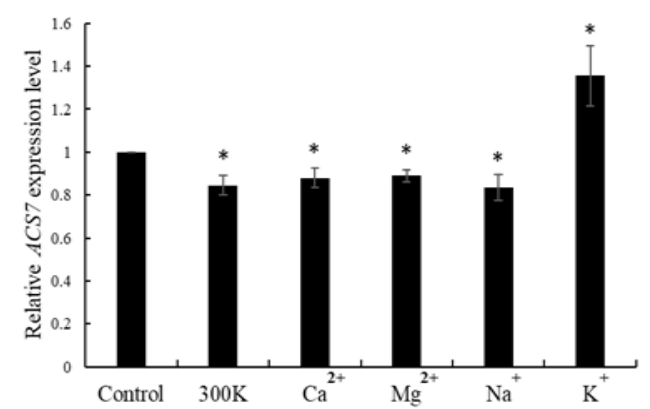

Figure 4. Relative RNA expressions of ethylene-biosynthesis genes (ACS7 and ACO2) in Arabidopsis thaliana plants under various SW and ionic treatments

Total RNA in all tested plants was extracted from leaves of two-week-old plants subjected for one week to diluted RO3, 300K, 340K, and 300K-Test, followed by ACS7 (A) and ACO2 (B) gene expressions.

Panel C is of two-week-old plants treated for one week with diluted $300 \mathrm{~K}$, and individual $\mathrm{Mg}^{2+}, \mathrm{Na}^{+}, \mathrm{K}^{+}$, and $\mathrm{Ca}^{2+}$ ions, followed by the relative RNA expression of the ACS7 gene.

Relative amounts were calculated and normalized with respect to the AtActin- 8 gene. Controls were Arabidopsis thaliana plants grown in 1/2 MS medium without SW and ionic treatments. Values are the means of eight replicates with corresponding standard deviations. The relative ACS7 and ACO2 gene expressions are in comparison to control plants, and an asterisk indicates a significance level of $p \leq 0.05$

Figure 5A shows that the ethylene level of three-week-old plants under $300 \mathrm{~K}$ treatment $(0.085 \mathrm{ppm})$ was significantly lower than in controls $(0.105 \mathrm{ppm})$. Furthermore, ethylene levels in all tested plants in all ionic treatments $(0.09 \sim 0.1 \mathrm{ppm})$ were significantly lower in controls $(0.12 \mathrm{ppm})$ after exogenously applied $1 \mu \mathrm{M}$ ethephon treatment for one week, whereas ethylene levels in all plants in all ionic treatments were close to the levels of controls ( $0.105 \mathrm{ppm}$ ) without ethephon treatment (Figure 5B). These results suggest that leaf senescence depends on the balance between ACS7-generated ethylene and ionic-dependent ethylene accumulation in Arabidopsis. Ethephon is an ethylene production inducer and is chemically converted to ethylene by oxidation. Ethylene biosynthesis occurs in all plant tissues and throughout all stages of leaf development, but endogenous ethylene levels vary according to the stage of leaf growth and development (Iqbal et al., 2017), which can be promoted or inhibited by ethylene, coupled with an increase or decrease in ACC synthesis, respectively (Ceusters and VandePoel, 2018). Plants at different developmental stages or with different genetic backgrounds express ACO at different levels, leading to regulation of ethylene production (Kim et al., 2003). Sun et al. (2017) reported that ACS7 degradation is highly regulated by senescence signals to enable optimal ethylene production at the appropriate times during At leaf development. 
A.

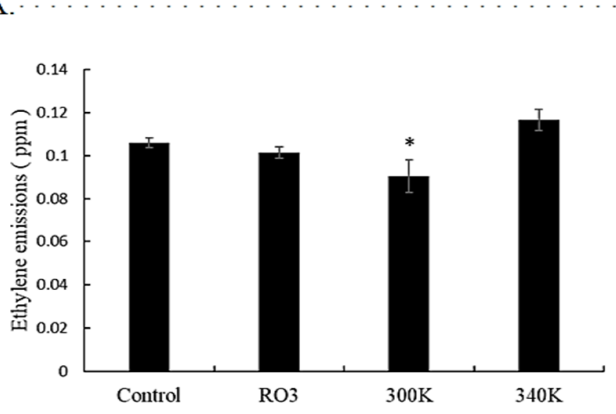

B.

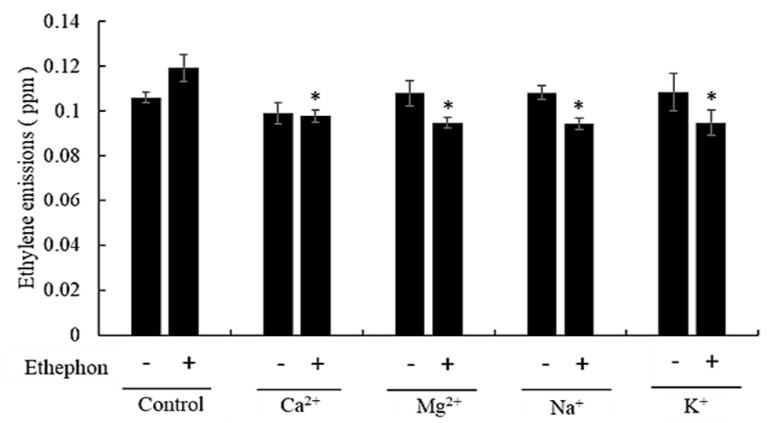

Figure 5. Ethylene emissions of four-week old potted Arabidopsis thaliana plants treated for one week with diluted $\mathrm{RO} 3,300 \mathrm{~K}, 340 \mathrm{~K}$ and individual $\mathrm{Mg}^{2+}, \mathrm{Na}^{+}, \mathrm{K}^{+}$, and $\mathrm{Ca}^{2+}$

(A) Ethylene emissions within 2 min after diluted SW treatments. Controls were Arabidopsis thaliana plants grown in $1 / 2 \mathrm{MS}$ medium without SW treatments.

(B) Ethylene emissions within $2 \mathrm{~min}$ after individual ionic treatments with (+) or without (-) $1 \mathrm{mM}$ ethephon. Controls were Arabidopsis thaliana plants grown in 1/2 MS medium with or without ethephon treatments.

Values are the means of eight replicates with corresponding standard deviations. Ethylene emission is compared to control plants and an asterisk indicates a significance level of $p \leq 0.05$.

\section{treatment}

Ethylene production and expressions of senescence-associated genes in At plants with ethephon

Relative RNA expressions of NAP, SAG113, and WRKY6 genes involved in the senescence response were analyzed for the possibility that ethylene is involved in the signaling pathways of NAP, SAG113, and WRKY6genes. Figure 6A shows that significant up-regulated expressions of NAP, SAG113, and WRKYG were observed in plants treated with ethephon $(>2.2)$ compared to non-ethephon treatment $(=1)$. Nevertheless, when those plants were subjected to $300 \mathrm{~K}, \mathrm{Ca}^{2+}, \mathrm{Mg}^{2+}$, and $\mathrm{Na}^{+}$treatments, all expressions of NAP, SAG113, and $\operatorname{WRKYG}(<0.7)$ were significantly lower than in control plants $(=1)$ (Figures 6B-D). Moreover, RNA levels of $N A P$ and $S A G 113$ in plants under $\mathrm{K}^{+}$treatment were significantly higher $(=1.2)$ and lower $(0.38)$, respectively, than in controls $(=1)$ (Figures $6 \mathrm{~B}, \mathrm{C}$ ). These differences in gene expression may be because of the influence that major ions in SW have on the ethylene biosynthesis of At plants. This study used a mixture of these major ions to prepare the SW used to culture At plants in the attempt to understand the influence that the major ions in SW have on regulating ethylene-produced pathways. The results suggest that the combination of the four individual ionic waters may have a synergistic effect on the regulation of ethylene biosynthesis. These findings can serve as a valuable reference for improving electric dialysis and water separation techniques based on SW.

Aging factors NAP, SAG113, and WRKY6 play important roles in delaying senescence, with different signaling pathways in these ionic-treated At plants. After ethephon application and ionic treatments of At plants, the up-regulation of NAP, SAG113, and WRKY6 gene expressions and obviously decreased ethylene content delayed senescence during plant development compared to control plants. The down-regulation of these senescence-associated genes in the ionic-treated plants activated the expression of the downstream target ACS7 gene that was also down-regulated in expression in $\mathrm{Ca}^{2+}, \mathrm{Mg}^{2+}$, and $\mathrm{Na}^{+}$-treated plants, but was highly expressed in $\mathrm{K}^{+}$-treated plants compared to control plants. Consequently, these ions acted as a signal to NAP, SAG113, and WRK6 genes and activated gene products involved in ethylene acclimation and tolerance of ethylene-downregulated pathway in ionic-treated plants. Both ethylene and $\mathrm{Ca}^{2+}$ have been documented to play important roles in plant senescence. A balanced and timely supply of $\mathrm{Ca}^{2+}$ sources for fruit and vegetable crops during the growing season and at the postharvest stage improves the shelf life and nutritional quality of horticultural produce (Gao et al., 2019). Furthermore, $\mathrm{Ca}^{2+}$ supply to ornamental crops extends the vase-life of flowers by delaying senescence and reducing intensified ethylene production (Aghdam et al., 2012). When the $\mathrm{Ca}^{2+}$ concentration changes, plants use a $\mathrm{Ca}^{2+}$ effector protein to sense this signal, and then manage external 
stimulation by regulating the expression of the plant stress gene. The $\mathrm{Ca}^{2+}$ signaling process is activated with the presence of a $\mathrm{Ca}^{2+}$ sensor and their target proteins (Zhang et al., 2018).

Monitoring the expressions of plant genes at the transcriptional level is an essential step in their functional analysis. Expression patterns in $A C S 7$ and $A C O 2$ in response to $\mathrm{SW}$ and ionic treatment stress provide a molecular basis for the ethylene biosynthesis pathway in plants. Thus, down-regulation in the ACS7 gene in 300K-treated plants (Figure 4) reduced ethylene content (Figure 5), but increased Chl, total phenol, and DPPH radical scavenging accumulations (Figures 2 and 3) and strengthened salt tolerance in 300K-treated plants. The expression profile of the ACS7 gene in control plants and with $300 \mathrm{~K}, \mathrm{Ca}^{2+}, \mathrm{Mg}^{2+}$, and $\mathrm{Na}^{+}$ treatments (Figure 4C) was correlated with decreases in NAP, SAG113, and WRKY6 gene expressions (Figures 6B-D). These ionic-induced transcriptional activations of senescence-associated genes correspond to decreases in the products of NAP, SAG113, and WRKY6 genes that protect cellular components against the effects of ROS accumulation as a consequence of delaying senescence.

A.

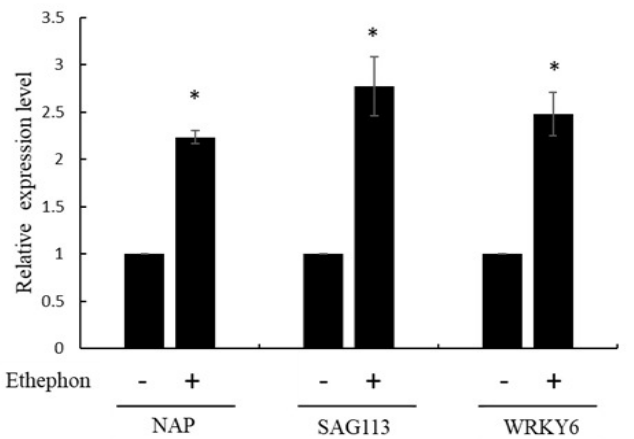

C.

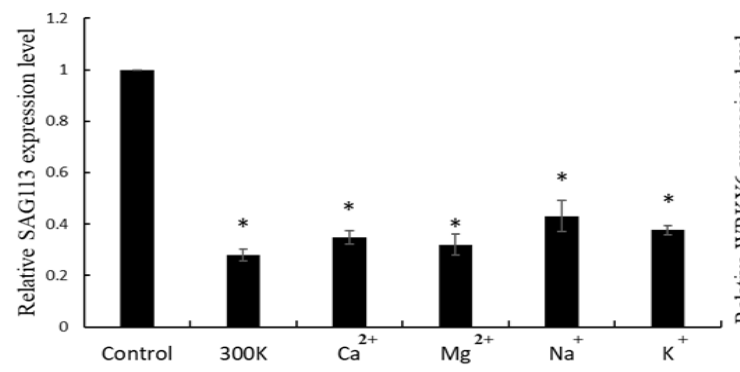

B.

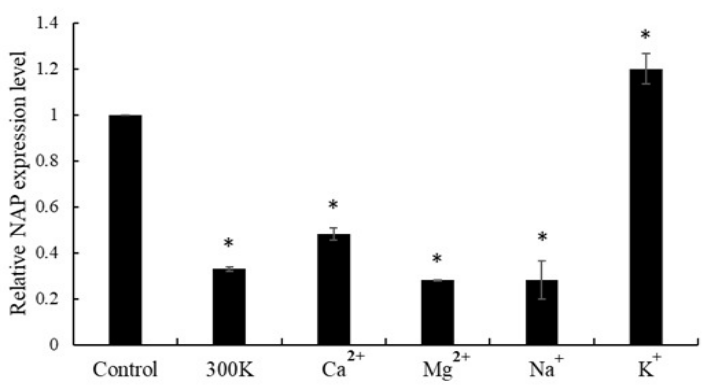

D.

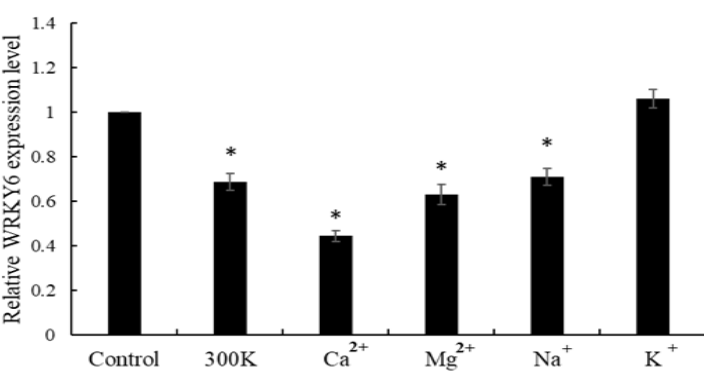

Figure 6. Relative RNA expressions of senescence-associated genes (NAP, SAG113, and WRKYG) in Arabidopsis thaliana plants

(A) Total RNA in all tested plants was extracted from leaves of two-week-old plants with $(+)$ or without $(-)$ ethephon $(1 \mathrm{mM})$ treatments for one week followed by NAP, SAG, and WRKY6 gene expressions. (B D) Total RNA in all tested plants was extracted from leaves of two-week-old plants subjected to $300 \mathrm{~K}, \mathrm{Ca}^{2+}, \mathrm{Mg}^{2+}, \mathrm{Na}^{+}$, and $\mathrm{K}^{+}$treatments for one week followed by NAP (B), SAG (C), and WRKY6 (D) gene expressions. Relative amounts were calculated and normalized with respect to the AtActin-8 gene. Controls were Arabidopsis thaliana plants grown in 1/2 MS medium without SW and ionic treatments. Values are the means of eight replicates with corresponding standard deviations. Relative $N A P, S A G 113$, and WRKY6 gene expressions are compared to control plants, and an asterisk indicates a significance level of $p \leq 0.05$. 
Ethylene is an important plant growth substance, and ethylene responses may interact with other physiological processes or responses. Hua and Meyerowitz (1998) reported that ethylene treatment results in leaf senescence coupled with a decrease in Chl content and up-regulation of the SAG2 expression. Figure 7 demonstrates a prediction of signaling transduction pathways of delaying senescence in Arabidopsis plants treated with $300 \mathrm{~K}$ DOW. The $\mathrm{Mg}^{+2}, \mathrm{Na}^{+}$, and $\mathrm{Ca}^{2+}$ in the $300 \mathrm{~K}$ solution decreased the expressions of NAP, SAG113, and WRKY6, leading to decreased ACS7 gene expression and reduced ethylene production, but expression of the $\mathrm{ACO} 2$ gene was not affected by $300 \mathrm{~K}$ treatment. The alternative pathway of $\mathrm{Ca}^{2+}$ in the diluted $300 \mathrm{~K}$ was to increase total phenol content and reduce the accumulation of free radicals (i.e., superoxide) that decrease plant aging from ethylene. However, the $\mathrm{K}^{+}$in the diluted $300 \mathrm{~K}$ inhibited SGA113 gene expression, resulting in reducing ACS7 gene expression and reducing ethylene production. Although the main ions in SW induced ethylene biosynthesis via transcriptional regulation, whether the signaling transduction pathways of delaying senescence in At plants were affected by trace elements in the SW in this study remain unknown.

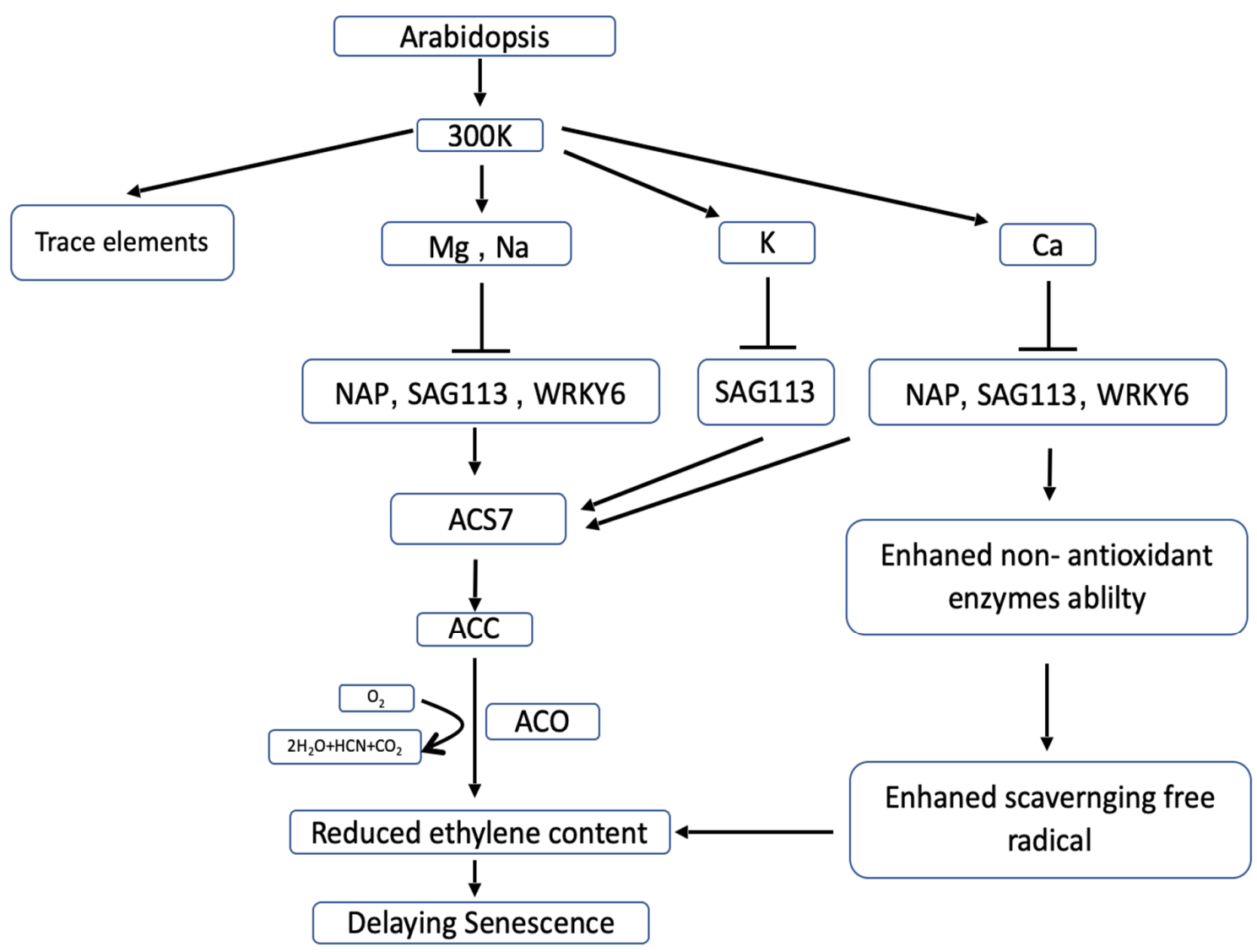

Figure 7. Schematic diagram of signaling transduction pathways for delaying senescence in Arabidopsis plants treated with diluted $300 \mathrm{~K} \mathrm{SW}$

The $\mathrm{Mg}^{+2}, \mathrm{Na}^{+}$, and $\mathrm{Ca}^{2+}$ in the $300 \mathrm{~K}$ solution decreased the expressions of NAP, SAG113, and WRKY6, leading to a decrease in ACS7 gene expression and reduction of ethylene production, but expression of the ACO2 gene was not affected. The alternative pathway of $\mathrm{Ca}^{2+}$ in the diluted $300 \mathrm{~K}$ was to increase total phenol content and reduce the accumulation of free radicals (i.e., superoxide) in order to decrease ethylene-caused plant aging. However, the $\mathrm{K}^{+}$in the diluted 300K inhibited SGA113 gene expression, resulting in reducing ACS7 gene expression and reducing ethylene production. 
The presence of NAP, SAG113, and WRKY6 transcripts in the $300 \mathrm{~K}-, \mathrm{Ca}^{2+}-, \mathrm{Mg}^{2+}$, and $\mathrm{Na}^{+}$-treated plants was a rapid response to ethylene content, indicating the importance of these genes in the ROS defense system in plant cells. The $300 \mathrm{~K}$-treated plants exhibited stronger resistance to ethylene tolerance due to less - $\mathrm{O}^{2-}$ accumulation. The senescence stress tolerance caused by $\mathrm{Ca}^{2+}$ treatment led to the reduced production of ethylene, consequently increasing total $\mathrm{Chl}$ and phenol content. The capacity of a plant to down-regulate the expression of NAP, SAG113, and WRKYG defines that plant's tolerance to $\mathrm{Ca}^{2+}$ stress, with enhanced transcription of these genes and subsequently increased total phenolic content and DPPH radical scavenging effects leading to reduced ethylene content and delayed senescence in plants. A high level of total phenol content and DPPH radical scavenging activity may result from the down-regulated expressions of ACS7, NAP, SAG113, and WRKY6 genes, which could eliminate ethylene induced $\bullet \mathrm{O}^{2-}$, and these genes in $300 \mathrm{~K}$ - and $\mathrm{Ca}^{2+}$-treated plants were involved in $\bullet \mathrm{O}^{2-}$ detoxification and thus helped overcome ethylene-induced stress. The $300 \mathrm{~K}$ - and $\mathrm{Ca}^{2+}$-treated plants with higher total phenol levels and DPPH radical scavenging activity were benefitted by an increased capacity in their ROS-scavenging system. The ethylene-induced transcriptional activation of NAP, SAG113, and WRKY6 genes corresponded to an increase in total phenol content and DPPH radical scavenging activity, which protected cellular components against the effects of ROS and ethylene. This will be helpful for precisely controlling ethylene production and signaling to enhance salinity tolerance and improve the agronomic traits of crops. Although ACS7, NAP, SAG113, and WRKYG play major roles in the biosynthesis of senescence ethylene and elucidate underlying mechanisms, how plants coordinate their ethylene biosynthesis with leaf senescence in the post-transcriptional regulation remains an area for further work.

\section{Conclusions}

Many lands and fields are located in coastal areas, and diluted SW can be considered a free local resource for possible use as irrigation. In present study, we found that the increased TTC activity in 300K SW suggests the enhance tissue cell viability of At plants. The $300 \mathrm{~K} \mathrm{SW}$ could down-regulation ACS7 gene and significantly reduced the ethylene content, but remarkably increased $\mathrm{Chl}$, phenol, and DPPH analyses and strengthened the salt tolerance. In addition, $\mathrm{Mg}^{2+}, \mathrm{Na}^{+}, \mathrm{K}^{+}, \mathrm{Ca}^{2+}$, and $300 \mathrm{~K}$ displayed lower levels of $\bullet \mathrm{O}^{2-}$ accumulation in leaves. The induction of ACS7-generated ethylene for leaf senescence was countered by NAP, SAG113, and WRKY6dependent $\mathrm{Ca}^{2+}, \mathrm{Mg}^{2+}$, and $\mathrm{Na}^{+}$accumulation; moreover, phenol content increased and NAP, SAG113, and WRKY6-induced leaf senescence occurred in non-senescing leaves. Nevertheless, $\mathrm{K}^{+}$treatment inhibited SGA113 gene expression, resulting in reducing ACS7 gene expression and ethylene content. The increased tolerance to salt by At plants that down-regulated the ACS7, NAP, SAG113, and WRKY6 genes suggests that these genes may be helpful in decreasing the ethylene content. The use of $300 \mathrm{~K} \mathrm{SW}$ caused a delay in leaf senescence, and this may be the primary cultural use for $\mathrm{Ca}^{2+}$. The characterization and functional analysis of these genes should facilitate our understanding of ethylene response mechanisms in plants.

\section{Authors' Contributions}

CMC conceived and designed the experiments; WJC, MYH, and SFP performed the experiments; YSC, $\mathrm{HCW}$, and HHL analyzed and interpreted the data; KHL and CMC prepared, wrote, and reviewed the manuscript. All authors read and approved the final manuscript. 
Lin K-H et al. (2021). Not Bot Horti Agrobo 49(1):12205

\section{Acknowledgements}

This research received no specific grant from any funding agency in the public, commercial, or not-forprofit sectors.

\section{Conflict of Interests}

The authors declare that there are no conflicts of interest related to this article.

\section{References}

Alet AI, Diego HS, Cuevas JC, Marina M, Carrasco P, Altabell T, ... Ruiz OA (2012). Plant Science 182:94-100. https://doi.org/10.1016/j.plantsci.2011.03.013

Alvarez-Aragon R, Rodriguez-Navarro A (2017). Nitrate-dependent shoot sodium accumulation and osmotic unctions of sodium in Arabidopsis under saline conditions. Plant Journal 91:208-219. https://doi.org/10.1111/tpj.13556

Arnon DI (1949). Copper enzymes in isolated chloroplasts, polyphenoxidase in Beta vulgaris. Plant Physiology 24:1-15. https://doi.org/10.1104/pp.24.1.1

Aghdam MS, Hassanpouraghdam MB, Paliyath G, Farmani B (2012). The language of calcium in postharvest life of fruits, vegetables and flowers. Scientia Horticulturae 144:102-115. https://doi.org/10.1016/j.scienta.2012.07.007

Atzori G, Nissim WG, Caparrotta S, Masi E, Azzarello E, Pandolfi C, ... Mancuso S (2016). Potential and constraints of different seawater and freshwater blendsas growing media for three vegetable crops. Agriculture Water Management 176:255-262. https://doi.org/10.1016/j.agwat.2016.06.016

Balal RM, Khan MM, Shahid M, Mattson NS, Abbas T, Ashfaq M, ... Iqbal Z (2012). Comparative studies on the physiobiochemical, enzymatic, and ionic modifications in salt-tolerant and salt-sensitive citrus rootstocks under $\mathrm{NaCl}$ stress. Journal of American Society of Horticulture Science 137:86-95. https://doi.org/10.21273/JASHS.137.2.86

Caparrotta S, Masi E, Atzori G, Diamanti I, Azzarello E, Mancuso S, Pandolfi C (2019). Growing spinach (Spinacia oleracea) with different seawater concentrations: Effects on fresh, boiled and steamed leaves. Scientia Horticulturae 256:108540. https://doi.org/10.1016/j.scienta.2019.05.067

Ceusters J, Van de Poel B (2018). Ethylene exerts species-specific and age-dependent control of photosynthesis. Plant Physiology 176:2601-2612. https://doi.org/10.1104/pp.17.01706

Cao WH, Liu J, He XJ, Mu RL, Zhou HL, Chen SY, Zhang JS (2007). Modulation of ethylene responses affects plant salt-stress responses. Plant Physiology 143:707-719. https://doi.org/10.1104/pp.106.094292

Chiang CM, Kuo WS, Lin KH (2014). Cloning and gene expression analysis of sponge gourd ascorbate peroxidase gene and winter squash superoxide dismutase gene under respective flooding and chilling stresses. Horticulture, Environment and Biotechnology 55:129-137. https://doi.org/10.1007/s13580-014-0116-4

Ding J, Yang T, Feng H, Dong M, Slavin M, Xiong S, Zhao S (2016). Enhancing contents of r-aminobutyric acid (GABA) and other micronutrients in dehulled rice during germination under normoxic and hypoxic conditions. Journal of Agriculture and Food Chemistry 64:1094-1102. https://doi.org/10.1021/acs.jafc.5b04859

Dewanto V, Wu X, Adom KK, Hai L, Liu R (2002). Thermal processing enhances the nutritional value of tomatoes by increasing total antioxidant activity. Journal of Agriculture and Food Chemistry 50:3010-3014. https://doi.org/10.1021/jf0115589

Dong H, Zhen Z, Peng J, Chang L, Gong Q, Wang NN (2011). Loss of ACS7 confers abiotic stress tolerance by modulating ABA sensitivity and accumulation in Arabidopsis. Journal of Experimental Botany 62:4875-4887. https://doi.org/10.1093/jxb/err143

Errabii T, Gandonou CB, Essalmani H, Abrini J, Idaomar M, Skali-Senhaji N (2006). Growth, proline and ion accumulation in sugarcane callus cultures under drought-induced osmotic stress and its subsequent relief. African Journal of Biotechnology 5(16):1488-1493. https://doi.org/10.4314/ajb.v5i16.43144 
Foyer CH, Lopez DH, Date JF, Scott IM (1997). Hydrogen peroxide and glutathione associated mechanisms of acclamatory stress tolerance and signaling. Physiologia Plantarum 100:241-254.

https://doi.org/10.1034/j.1399-3054.1997.1000205.x

Gao Q, Xiong T, Li X, Chen W, Zhu X (2019). Calcium and calcium sensors in fruit development and ripening. Scitifia Horticulturae 253:412-421. https://doi.org/10.1016/j.scienta.2019.04.069

Garcia-Sanchez F, Syvertsen JP (2009). Substrate type and salinity affect growth allocation, tissue ion concentrations, and physiological responses of Carrizo citrange seedlings. HortScience 44:1432-1437.

https://doi.org/10.21273/HORTSCI.44.5.1432

Gonzalez P, Syvertsen JP, Etxeberria JP (2012). Sodium distribution in salt-stressed citrus rootstock seedlings. HortScience 47:1504-1511. https://doi.org/10.21273/HORTSCI.47.10.1504

Gu L, Ma Q, Zhang C, Wang C, Wei H, Wang H, Yu S (2019). The cotton GhWRKY91 transcription factor mediates leaf senescence and responses to drought stress in transgenic Arabidopsis thaliana. Frontiers in Plant Science 10:1352. https://doi.org/10.3389/fpls.2019.01352

Higgins MF, Rudkin B, Kuo CH (2019). Oral ingestion of deep ocean minerals increases high-intensity intermittent running capacity in soccer players after short-term post-exercise recovery: A double-blind, placebo-controlled crossover trial. Marine Drugs 17:309. https://doi.org/10.3390/md17050309

Hoque A, Banu NA, Okuma E, Amakpo K, Nakamura Y, Shimoishi Y, Murata Y (2007). Exogenous proline and glycinebetaine increase $\mathrm{NaCl}$-induced ascorbate-glutathione cycle enzyme activities, and proline improves salt tolerance more than glycinebetaine in tobacco bright yellow-2 suspension-cultured cells. Journal of Plant Physiology 164:1457-1468. https://doi.org/10.1016/j.jplph.2006.10.004

Hua J, Meyerowitz EM (1998). Ethylene responses are negatively regulated by a receptor gene family in Arabidopsis thaliana. Cell 94:261-271. https://doi.org/10.1016/S0092-8674(00)81425-7

Hussain MI, Reigosaa MJ (2014). Higher peroxidase activity, leaf nutrient contents and carbon isotope composition changes in Arabidopsis thaliana are related to rutin stress. Journal of Plant Physiology 171:1325-1333. https://doi.org/10.1016/j.jplph.2014.05.009

Hwang SY, VanToai TT (1991). Abscisic acid induces anaerobiosis tolerance in corn. Plant Physiology 97:593-597. https://doi.org/10.1104/pp.97.2.593

Iqbal N, Khan NA, Ferrante A, Trivellini A, Francini A, Khan MIR (2017). Ethylene role in plant growth, development and senescence: interaction with other phytohormones. Frontiers in Plant Science 8:475. https://doi.org/10.3389/fpls.2017.00475

Janicka-Russak M, Kabała K, Wdowikowska A, Kłobus G (2013). Modification of plasma membrane proton pumps in cucumber roots as an adaptation mechanism to salt stress. Journal of Plant Physiology 170(10):915-922. https://doi.org/10.1016/j.jplph.2013.02.002

Julkowska MM, Testerink C (2015). Tuning plant signaling and growth to survive salt. Trends in Plant Science 20:586594. https://doi.org/10.1016/j.tplants.2015.06.008

Islam S, Hagimine T, Ishikawa K, Takeda N, Azad MAK, Miyauchi K (2010). Growth and fruit quality responses of hydroponically cultivated eggplants to mineral controlled deep-sea water. Journal of Plant Nutrition 33:19701979. https://doi.org/10.1080/01904167.2010.512055

Jung SJ, Joo EJ (2006). Effect of the supply of natural water from deep sea rock on the immune response and antioxidant activity in rats. Journal of Animal Science 48:211-215. https://doi.org/10.5187/JAST.2006.48.2.211

Kang SM, Jhoo J W, Pak JI, Kwon IK, Lee SK, Kim GY (2015). Effect of yogurt containing deep sea water on healthrelated serum parameters and intestinal microbiota in mice. Journal of Dairy Science 98(9):5967-5973. https://doi.org/10.3168/jds.2015-9492

Kim CY, Liu Y, Thorne ET, Yang H, Fukushige H, Gassmann W, ... Zhang S (2003). Activation of a stress-responsive mitogen activated protein kinase cascade induces the biosynthesis of ethylene in plants. Plant Cell 15:2707-2718. https://doi.org/10.1105/tpc.011411

Krishnan S, Emily B, Merewitz B (2015). Phytohormone responses and cell viability during salinity stress in two creeping Bent grass cultivars differing in salt tolerance. Journal of American Society of Horticultural Science 140:346-355. https://doi.org/10.21273/JASHS.140.4.346

Kosugi H, Kikugawa K (1985). Thiobarbituric acid reaction of aldehydes and oxidized lipids in glacial acetic acid. Lipids 20:915-920. https://doi.org/10.1007/BF02534777

Kou X, Watkins CB, Gan SS (2012). Arabidopsis AtNAP regulates fruit senescence. Journal of Experimental Botany 63:6139-6147. https://doi.org/10.1093/jxb/ers266 
Lin KH, Chiou YK, Hwang SY, Chen LFO, Lo HF (2008). Calcium chloride enhances the antioxidative system of sweet potato (Ipomoea batatas) under flooding stress. Annals of Applied Biology 152:157-168. https://doi.org/10.1111/j.1744-7348.2007.00211.x

Lin KH, Seib SC, Su YH, Chiang CM (2019). Overexpression of the Arabidopsis and winter squash superoxide dismutase genes enhances chilling tolerance via ABA-sensitive transcriptional regulation in transgenic Arabidopsis. Plant Signaling \& Behavior 14(12):1685728. https://doi.org/10.1080/15592324.2019.1685728

Lin KH, Pu SF (2010). Tissue- and genotype-specific ascorbate peroxidase expression in sweet potato in response to salt stress. Biologia Plantarum 54:664-670. https://doi.org/10.1007/s10535-010-0118-8

Linkies A, Müller K, Morris K, Turečková V, Wenk M, Cadman CS, Leubner-Metzger G (2009). Ethylene interacts with abscisic acid to regulate endosperm rupture during germination: a comparative approach using Lepidium sativum and Arabidopsis thaliana. Plant Cell 21:3803-3822. https://doi.org/10.1105/tpc.109.070201

Livak KJ, Schmittgen TD (2001). Analysis of relative gene expression data using real-time quantitative PCR and the 2(Delta DeltaC(T)) method. Methods 25:402-408. https://doi.org/10.1006/meth.2001.1262

Lyzenga WJ, Judith KB, Stone SL (2012). The Arabidopsis RING-type E3 ligase XBAT32 mediates the proteasomal degradation of the ethylene biosynthetic enzyme, 1-aminocyclopropane-1-carboxylate synthase 7 . The Plant Journal 71:23-34. https://doi.org/10.1111/j.1365-313X.2012.04965.x

Maathuis FJM (2006). The role of monovalent cation transporters in plant responses to salinity. Journal of Experimental Botany 57:1137-1147. https://doi.org/10.1093/jxb/erj001

Millero FJ, Feistel R, Wright DG, McDougall TJ (2008). The composition of standard seawater and the definition of the reference-composition salinity scale. Deep Sea Research Part I: Oceanographic Research Papers 55(1):50-72. https://doi.org/10.1016/j.dsr.2007.10.001

Munns R (2002). Comparative physiology of salt and water stress. Plant, Cell and Environment 25:239-250. https://doi.org/10.1046/j.0016-8025.2001.00808.x

Nakagawa K, Yokoyama Y, Nakajima H, Ikegami Y (2000). Application of minerals in deep sea water. JADOWA Deep Ocean Water Research 1:1-4. https://doi.org/10.1016/0146-6291(78)90619-7

Nakano Y, Asada K (1981). Hydrogen peroxide is scavenged by ascorbate-specific peroxidase in spinach chloroplasts. Plant Cell Physiology 22:67-880. https://doi.org/10.1093/oxfordjournals.pcp.a076232

Nani M, Zura S, Majid FAA, Jaafar AB, Mahdzir A, Musa MN (2016). Potential health benefits of deep-sea water: a review. Evidence-Based Complementary and Alternative Medicine https://doi.org/10.1155/2016/6520475

Nguyen HC, Lin KH, Ho SL, Chiang CM, Yang CM (2018). Enhancing the abiotic stress tolerance of plants: from chemical treatment to biotechnological approaches. Physiologia Plantarum 164:452-466. https://doi.org/10.1111/ppl.12812

Niu Y, Chen P, Zhang Y, Wang Z, Hu S, Jin G, Tang C, Guo L (2018). Natural variation among Arabidopsis thaliana accessions in tolerance to high magnesium supply. Scientific Report 8:13640.

https://doi.org/10.1038/s41598-018-31950-0

Parida AK, Das AB (2005). Salt tolerance and salinity effects on plants: A review. Ecotoxicology and Environmental Safety 60:324-349. https://doi.org/10.1016/j.ecoenv.2004.06.010

Peng J, Li Z, Wen X, Li W, Shi H, Yang L (2014). Salt-induced stabilization of EIN3/EIL1 confers salinity tolerance by deterring ROS accumulation in Arabidopsis. PLoS Genetics 10:e1004664. https://doi.org/10.1371/journal.pgen.1004664

Pérez-López U, Miranda-Apodaca J, Muñoz-Rueda A, Mena-Petite A (2013). Lettuce production and antioxidant capacity are differentially modified by salt stress and light intensity under ambient and elevated $\mathrm{CO}_{2}$. Journal of Plant Physiology 170(17):1517-1525. https://doi.org/10.1016/j.jplph.2013.06.004

Robatzek S, Somssich IE (2002). Targets of AtWRKY6 regulation during plant senescence and pathogen defense. Genetic Development 16:1139-1149. https://doi.org/10.1101/gad.222702

Sakamoto K, Kogi M, Yanagisawa T (2014). Effects of salinity and nutrients in seawater on hydroponic culture of red leaf lettuce. Environmental Control in Biology 52:189-195. https://doi.org/10.2525/ecb.52.189

Saito T, Fukuda N, Matsukura C, Nishimura S (2009). Effects of salinity on distribution of photosynthates and carbohydrate metabolism in tomato grown using nutrient film technique. Journal of Japanese Society of Horticultural Sciences 78:90-96. https://doi.org/10.2503/jjshs1.78.90 
Sekeli R, Abdullah JO, Namasivayam P, Muda P, Bakar UK, Yeong WC, Pillai V (2014). RNA interference of 1aminocyclopropane-1-carboxylic acid oxidase ( $A C O 1$ and $A C O 2)$ genes expression prolongs the shelf life of eksotika (Carica papaya L.) papaya fruit. Molecules 19:8350-8362. https://doi.org/10.3390/molecules19068350

Shafi A, Dogra V, Gill T, Ahuja PS, Sreenivasulu Y (2014). Simultaneous over-expression of PaSOD and RaAPX in transgenic Arabidopsis thaliana confers cold stress tolerance through increase in vascular lignification. PLos ONE 9: e110302. https://doi.org/10.1371/journal.pone.0110302

Shimada K, Fujikawa K, Yahara K, Nakamura T (1992). Antioxidative properties of xanthan on the autoxidation of soybean oil in cyclodextrin emulsion. Journal of Agriculture Food Chemistry 40:945-948. https://doi.org/10.1021/jf00018a005

Shiraishi H, Fujino M, Shirakawa N, Ishida N, Funato H, Hirata A, ... Miyamura M (2017). Effect of minerals on intestinal IgA production using deep sea water drinks. Biological and Pharmaceutical Bulletin 40(10):1700-1705. https://doi.org/10.1021/jf00018a005

Sohrin Y, Iwamoto SI, Akiyama S, Fujita T, Kugii T, Obata H, Matsui M (1998). Determination of trace elements in seawater by fluorinated metal alkoxide glass-immobilized 8-hydroxyquinoline concentration and high-resolution inductively coupled plasma mass spectrometry detection. Analytica Chimica Acta 363(1):11-19.

https://doi.org/10.1016/S0003-2670(98)00074-9

Sun G, Mei Y, Deng D, Xiong L, Sun L, Zhang X, ... Wang NN (2017). N-t erminus-mediated degradation of ACS7 is negatively regulated by senescence signaling to allow optimal ethylene production during leaf development in Arabidopsis. Frontiers in Plant Science 8:2066. https://doi.org/10.3389/fpls.2017.02066

Tenhaken R (2014). Cell wall remodeling under abiotic stress. Frontiers in Plant Science 5:771. https://doi.org/10.3389/fpls.2014.00771

Turhan A, Kuscu H, Ozmen, N, Serbeci MS, Demir AO (2014). Effect of different concentrations of diluted seawater on yield and quality of lettuce. Chilean Journal of Agriculture Research 74:111-116. https://doi.org/10.4067/S0718-58392014000100017

Wen CK, Tucker M (2015). Research tool: ethylene preparation: treatment with ethylene and its replacements. In: Ethylene in Plants. Springer, Dordrecht pp 245-261. https://doi.org/10.1007/978-94-017-9484-8_1

.Xie WJ, Chen YS, Wu HV, Pan SF, Lin KH, Chiang CM (2020). Analysis the cell viability activity and antioxidant ability of pakchoi and tomato by deep ocean water. Ming Chung-Transaction in Biotechnology 11:e1. https://doi.org/10.1201/9781439843390-c6

Yang SF, Hoffman NE (1984). Ethylene biosynthesis and its regulation in higher plants. Annual Review of Plant Physiology 35:155-189. https://doi.org/10.1146/annurev.pp.35.060184.001103

Yamada H, Takimoto S, Toshinari D, Kataoka K, Habu T (2015). Effect of seawater irrigation on water relations and fruit quality in potted citrus trees. Horticulture Journal 84:195-201. https://doi.org/10.2503/hortj.MI-022

Yudi C, Takahisa M, Suhardiyanto, H, Susila AD (2007). Application of deep-sea water for nutrient supplement in hydroponics cultivation of tomato: Effect of supplemented DSW at different EC levels on fruit properties. Indonesian Journal of Agronomy 35:118-126. https://doi.org/10.17660/ActaHortic.2007.761.61

Yuan F, Yang H, Xue Y, Kong D, Ye R, Li C, ... Pei ZM (2014). OSCA1 mediates osmotic- stress-evoked Ca ${ }^{2+}$ increases vital for osmosensing in Arabidopsis. Nature 514(7522):367-371. https://doi.org/10.1038/nature13593

Zhang Z, Gan SS (2012). An abscisic acid- AtNAP transcription factor-SAG113 protein phosphatase 2C regulatory chain for controlling dehydration in senescing Arabidopsis leaves. Plant Physiology 158:961-969. https://doi.org/10.1104/pp.111.190876

Zhang Y, Yang L, Chen G, Ren D, Guo L (2018). Sensing of abiotic stress and ionic stress responses in plants. International Journal of Molecular Science 19:3298. https://doi.org/10.1002/9781118764374.ch8 
OPEN ACCESS

(c) (2)

The journal offers free, immediate, and unrestricted access to peer-reviewed research and scholarly work. Users are allowed to read, download, copy, distribute, print, search, or link to the full texts of the articles, or use them for any other lawful purpose, without asking prior permission from the publisher or the author.

License - Articles published in Notulae Botanicae Horti Agrobotanici Cluj-Napoca are Open-Access, distributed under the terms and conditions of the Creative Commons Attribution (CC BY 4.0) License. (C) Articles by the authors; UASVM, Cluj-Napoca, Romania. The journal allows the author(s) to hold the copyright/to retain publishing rights without restriction. 